\title{
モリブデン/ジルコニア系ホットプレス 複合焼結体における熱膨張係数の異方性
}

\author{
江莞 ${ }^{\dagger}$ 渡 辺龍三 \\ 山田葉子川崎亮
}

東北大学工学部材料加工学科

J. Japan Inst. Metals, Vol. 60, No. 1 (1996), pp. 50-55

Anisotropy of Thermal Expansion Coefficient in Hot Pressed Mo/PSZ Composites

Wan Jiang ${ }^{\dagger}$, Ryuzo Watanabe, Yoko Yamada and Akira Kawasaki

Department of Materials Processing, Faculty of Engineering, Tohoku University, Sendai 980-77

The anisotropy of the thermal expansion coefficient in hot pressed particulate composites of molybdenum/partially stabilized zirconia was measured over a whole composition range by the laser speckle photography that had been specifically designed for the determination of regional thermal displacement in a sintered compact. On the presumption that the anisotropy is closely related to the microstructural orientation resulted from the uniaxial loading of hot pressing, the flattening and preferred orientation of the dispersed particles were quantified using the concept of equivalent ellipsoids and also with an anisotropic parameter, i.e. the deviation angle distribution. The definite anisotropy in the thermal expansion coefficients has been found; the thermal expansion coefficient parallel to the hot pressing direction is larger than that in the normal direction. It has been found that the difference in the thermal expansion coefficient is dependent on the composition with the largest difference at around 60 vol\%PSZ. The anisotropy (difference in the thermal expansion coefficient between the two directions) is linearly related to the anisotropic parameter that represents the particle orientation. The dependence of thermal expansion coefficient on the oriented particle distribution has been discussed by the Eshelby's theory. The experimental trend has been well explained by the present prediction.

(Received August 24, 1995)

Keywords: molybdenum, partially stabilized zirconia, hot pressing, thermal expansion coefficient, anisotropy, laser speckle photography, functionally graded materials

\section{I . 緒言}

著者らは傾斜機能材料の機能設計(1)(2)のための基礎データと して種々の金属/セラミックス複合系について熱膨張係数の組 成依存性の測定を継続している(3)-(8). 前報(8)に打いて $1473 \mathrm{~K}$ までの熱膨張係数およびその試料内分布を決定できるレーザー

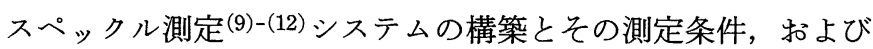
当システムを用いた $\mathrm{Mo} / \mathrm{PSZ}$ 系焼結複合材料の熱膨張係数の 実測について報告した。それによれば，上記測定法は非接触で 感度・精度ともに良好でしかもゲージ長が十分に短く, 焼結複 合材料の熱膨張係数の試料内分布を測定する方法としては最適 な方法の一つであることがわかった．

本研究は，ホットプレスで作製したモリブデン/ジルュニア

†東北大学大学院生, 現在 : (䏭)ケン(Graduate Student, Tohoku University. Present address: Riken Co. Ltd., Tokyo)
(以下 Mo/PSZ) 系焼結複合体に対して，その焼結組織の配向 性を起因する熱膨張係数の異方性を明らかにする目的で実施し た. 前記レーザースペックル測定システムにより種々の混合比 を有する $\mathrm{Mo} / \mathrm{PSZ}$ 系焼結複合材料のホットプレス方向扣よび それと垂直な方向の熱膨張係数を実測し，本系複合材料に括け る熱膨張係数の異方性と焼結組織の配向性との関連あるいは組 成依存性について検討した。

\section{II. 実 験 方 法}

\section{1. 焼結複合体の作製}

原料粉末として平均粒径 $3 \mu \mathrm{m}$ の Mo 粉末と, 平均粒径 0.07 $\mu \mathrm{m}$ の $3 \mathrm{~mol} \% \mathrm{Y}_{2} \mathrm{O}_{3}$ 添加 $\mathrm{ZrO}_{2}$ 粉末を用いた. 両粉末を湿式ボ ールミルにより $36 \mathrm{ks}$ 混合し $20,40,60,80 \mathrm{vol} \% \mathrm{PSZ}$ の混合粉 を調製した，得られた混合粉を内径 $30 \mathrm{~mm}$ の金型により 150 $\mathrm{MPa}$ で圧縮成形し, 直径 $30 \mathrm{~mm}$, 高さ約 $12 \mathrm{~mm}$ の圧粉体を 
作製し，さらに金型成形に伴う密度の不均一の除去のために $200 \mathrm{MPa}$ で静水圧加圧処理を施した。厈粉体を内径 $30 \mathrm{~mm} の$ 黒鉛型に装填し， $1773 \mathrm{~K}, 30 \mathrm{MPa}, 60 \mathrm{~min}$ の条件でホットプ レスした. Table 1 にアルキィデス法で求めたホットプレス焼 結体の相対密度を示す. Mo 単体と $80 \mathrm{vol} \% \mathrm{Mo}$ の組成の相対 密度はそれぞれ96.86和よび95.84\%と，やや低いが，他の組成 は100\%あるいは100\%に近い密度になっている。焼結体から $5 \mathrm{~mm} \times 5 \mathrm{~mm} \times 10 \mathrm{~mm}$ のブロックを切り出して熱膨張係数測 定用の試料とした.

\section{2. 組織配向性の定量}

焼結組織の配向分布を定量化するため, 分散相のアスペクト 比とその配向性を沉用の画像解析装置により湘定した. Fig. 1 に示したよらにまず任意の分散相粒子に対して，その粒子重 心のまわりの慣性モーメントを求めそれと等洒の棈円の長軸と 短軸の比(アスペクト比)を粒子の伸張度の目安とした。つい でホホットプレス荷重方向に対する棈円粒子の長軸の偏向角度 を定義し，顕微鏡断面上で1000～1200個の分散相粒子Kつい

Table 1 Relative densities for the HIPed and hot-pressed compacts $(1773 \mathrm{~K}, 30 \mathrm{MPa}, 1 \mathrm{~h}$, in vacuum $7 \mathrm{kPa})$.

\begin{tabular}{l|c}
\hline Composition & Relative density (\%) \\
\hline Mo & 96.86 \\
Mo +10 vol\%PSZ & - \\
Mo+20 vol\%PSZ & 95.84 \\
Mo+30 vol\%PSZ & - \\
Mo+40 vol\%PSZ & 98.95 \\
Mo+60 vol\%PSZ & 99.60 \\
Mo+80 vol\%PSZ & 99.87 \\
PSZ & 100.0 \\
\hline
\end{tabular}

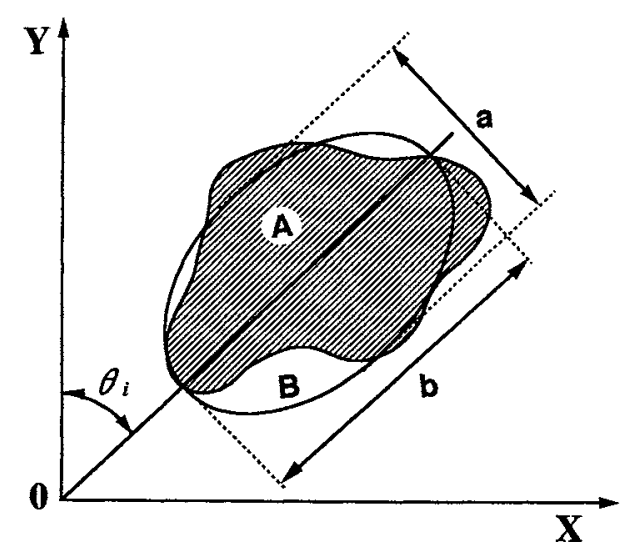

Fig. 1 Schematic drawing of the determination of the aspect ratio and orientation of a particle. The particle projection, $\mathrm{A}$, is represented with an equivalent ellipse, $B$. The aspect ratio is given as the ratio of long and short diameters, $b / a$. $\mathrm{Y}$ is the hot pressing direction. The particle orientation is presented by the angle between $Y$ axis and the direction of the main axis of the equivalent ellipse.
て偏向角度を測定し，配向分布を求めた。分散相の配向の程度 を平均的に表すためにTayaら(13)により提案された式(1)で 表される分散粒子配向パラメータ申を用いた。

$$
\phi=-\sum \cos 2 \theta_{\mathrm{i}} / N
$$

ここで， $\theta_{\mathrm{i}}$ は Y 軸炕対するi番目の粒子の相当棈円の長軸 の偏向角度， $N$ は測定対象となった粒子の総数である。この 場合， $\phi=1$ の場合はすべての粒子が Y 軸と垂直な力向に配向， $\phi=0$ の場合はランダム配向をしていることを表す。

\section{3. 熱膨張係数の測定 ${ }^{(8)}$}

本研究に用いたレーザースペックル撮影装置と画像解析シス テムは前報 ${ }^{(8)}$ と全く同様である。熱膨張係数の測定は，まず試 料を $573 \mathrm{~K}$ から.773 K まで昇温させて出発温度と最高温度で, スペックル写真を同一写真乾板上に二重露光撮影した。各温度 での撮影は設定温度になってからそこで $30 \mathrm{~min}$ 保持した後に 行った. 得られたスペックル像について, 画像解析システムに より，順次以下の三つのステップにより熱膨張係数を求めた. 第一ステップではスペックル写真から注目する方向の熱変位の 分布をポイントバイポイント法により測定する。第二ステップ ではカーブフィッティングにより熱変位分布の近似関数を求め その微分係数としての熱ひずみ分布を求める. 第三ステップで は熱ひずみ分布と測定温度から熱膨張係数を算出する。

試料のホットプレス方向とそれに垂直な方向の变位分布を求 めるために，撮影写真乾板上で試料の綐横両方向の中心軸に沿 ってレーザービームを再照射し，ヤングの干渉縞を再生してそ れから試料表面に打ける各点の絶対变位量を決定した。ここ で, レーザービームの移動距離は $0.25 \mathrm{~mm}$, 再生レーザービ 一ム径は前報同様 $0.2 \mathrm{~mm}$ とした。 得られた各点の変位量は直 径 $0.2 \mathrm{~mm}$ の領域内の平均変位量である.

\section{III. 結果および考察}

\section{1. 組織配向性の定量化}

Fig. 2 にホットプレスで得られた焼結複合体の光顕組織写 真を示す．観察面はホットプレス荷重に平行な切断面である. 写真化招いて白い部分はMo 相, 黒い部分はPSZ 相である. ホットプレス方向(図の綎方向) と垂直方向(図の横方向)に分散 粒子が扁平状になり，配向分布しているのがわかる．各組成に 対する組織を見ると，20 vol\%PSZ の組成では PSZ 相は細か く枝分かれの多いクラスター状の粒子の分散組織となって拉 り，配向性は見かけ上はそれ汪ぞ顕著ではないが，ややPSZ 粒子が横方向に配向しているのが認められる. 40 vol\%PSZの 組成では Mo 括よび PSZ の両相のネットワーク組織 ${ }^{(14)}$ になっ ており，この場合は配向性は規定できない。60执よび 80 vol\%PSZ の組成ではホットプレス方向に垂直方向に伸長した Mo 相が PSZ マトリックス中に配向分散する組織である。以 上の組織観察により，分散相粒子は焼結の際に一方向加圧のた 

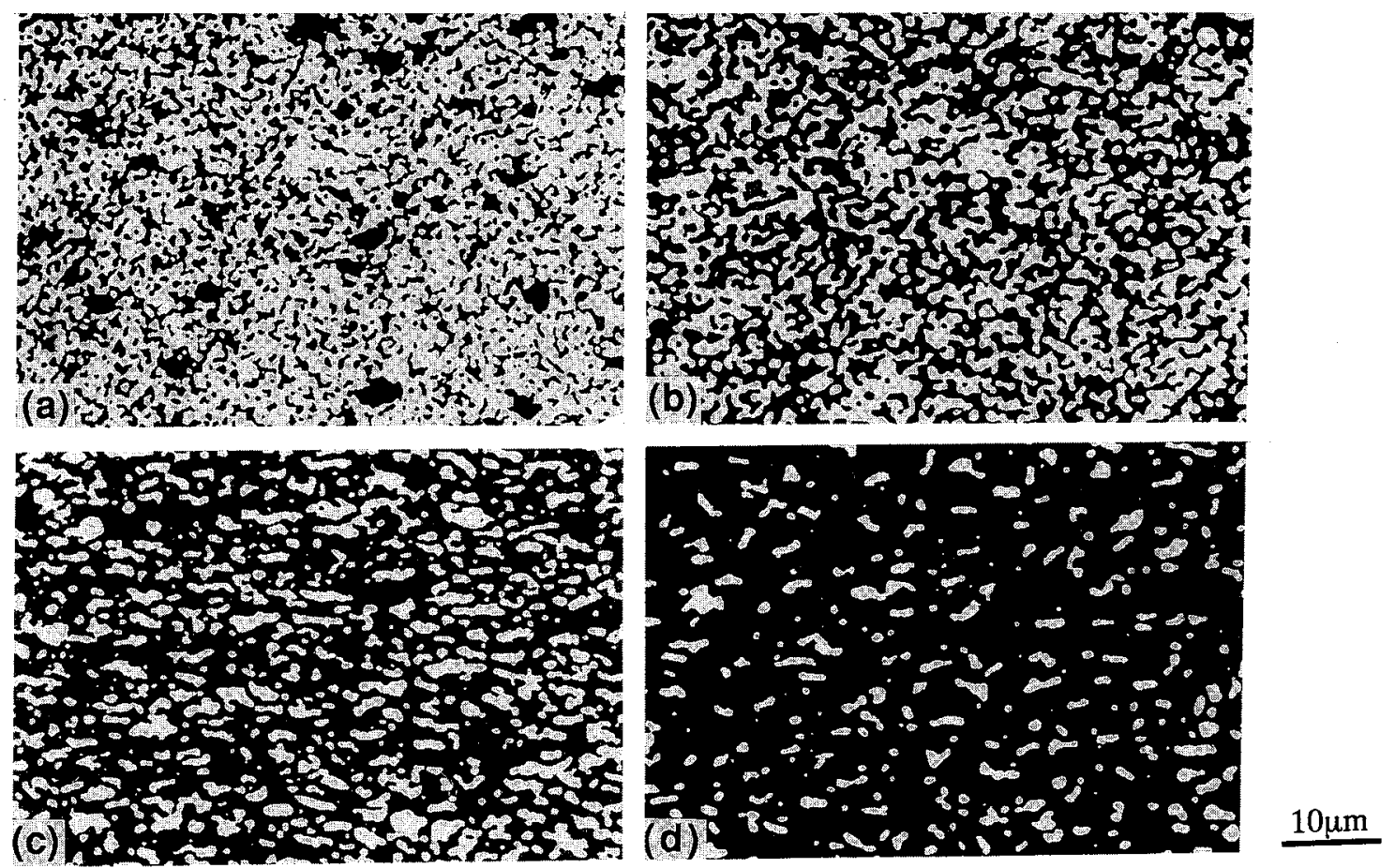

Fig. 2 Optical microstructures of sintered Mo/PSZ composites. The cross sections parallel to the hot-pressing direction. (a) Mo-20 vol $\%$ PSZ, (b) Mo-40 vol $\%$ PSZ, (c) Mo-60 vol $\%$ PSZ, (d) Mo- 80 vol\%PSZ.

め扁平状になりホットプレス方向と垂直な方向炕配向するこ とがわかる。

Fig. 3 に20,60和よび 80 vol\%PSZ に和ける分散相のアスペ クト比の分布を示す. 同図 (a) は PSZ 相，(b)および(c)はMo 相についての結果である。な抏，Mo-40 vol\%PSZ 試料につい ては，すでに述べたよらにネットワーク組織の発達が著しいた めアスペクト比は湘定していない. Table 2 に分散相粒子のア スペクト比の平均值を示す。一般に分散相粒子の平均アスペク ト比は 1 より大いが，Mo分散粒のアスペクト比の方が PSZ 相分散粒より大きくMo 分散粒のホットプレスによる扁 平化が大きいことがわかる。

Fig. 4 に分散相のホットプレス方向に対する配向分布の測 定結果を示す。ここで，横軸は分散相粒子のホットプレス方向 に対する偏向角度で，すでに述べたよらに $\theta=0^{\circ}$ のときホット プレス方向に平行， $\theta=90^{\circ}$ のときホットプレス方向に垂直で あることを表す。縦軸はそれぞれの方向に配向した粒子の数で ある、どの組成に执いてもホットプレス方向と垂直な方向の分 布頻度がそれと平行な力向の分布頻度より高い.しかもこの傾 向はMo 分散の場合の方が PSZ 分散の場合より顕著である。

Fig. 5 に式(3)で定義された配向パラメータを示す. 60 vol\%PSZでもっとも強い配向性を示す，一方，PSZ 分散で特

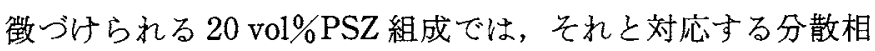
とマトリックスが逆転する $80 \mathrm{vol} \% \mathrm{PSZ}$ に比べて，分散粒の 配向性は弱い。これはホットプレス時の加圧による物質輸送促 進効果がMo 相により強く現れることを意味して叔り，この

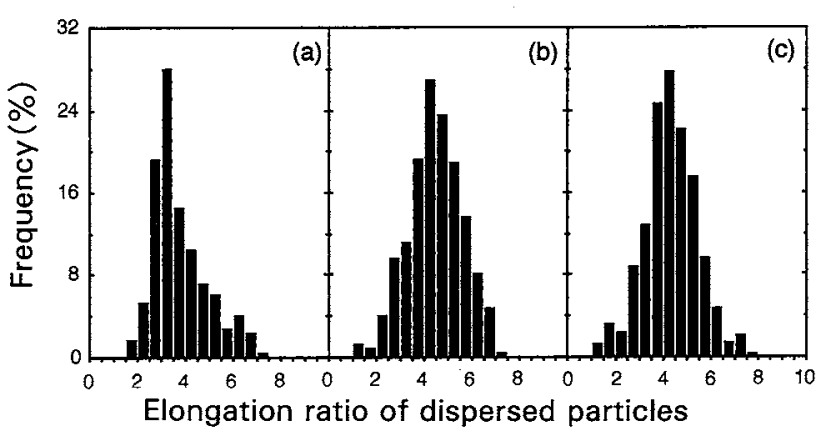

Fig. 3 Distribution of the aspect ratio of dispersion particles in hot-pressed Mo/PSZ composites.

((a) 20 vol\%PSZ, (b) 60 vol\%PSZ, (c) 80 vol\%PSZ).

種の複合材料の組織制御上興味ある点である。

\section{2. 熱膨張係数の異方性}

前項で述べたよらにホットプレスで作製した $\mathrm{Mo} / \mathrm{PSZ}$ 系複 合体は一力向加圧のため, 明らか炕組織に配向性が生じている ことがわかった．Fig. 6 にこのような複合体について，573 K から $773 \mathrm{~K}$ の温度範囲で測定したホットプレス方向に垂直抒 よび平行な方向の熱变位の分布を示す. 図の横軸は試料の底面 から測定点までの距離, 縦軸は試料の底面から積算された各点 の変位量である. 図中 X=0に和ける変位量は, 試料台の膨張 量である. 本図からいずれの組成においても変位量は測定位置 に対して直線的に变化して扣り, 垂直执よび水平の両方向とも 


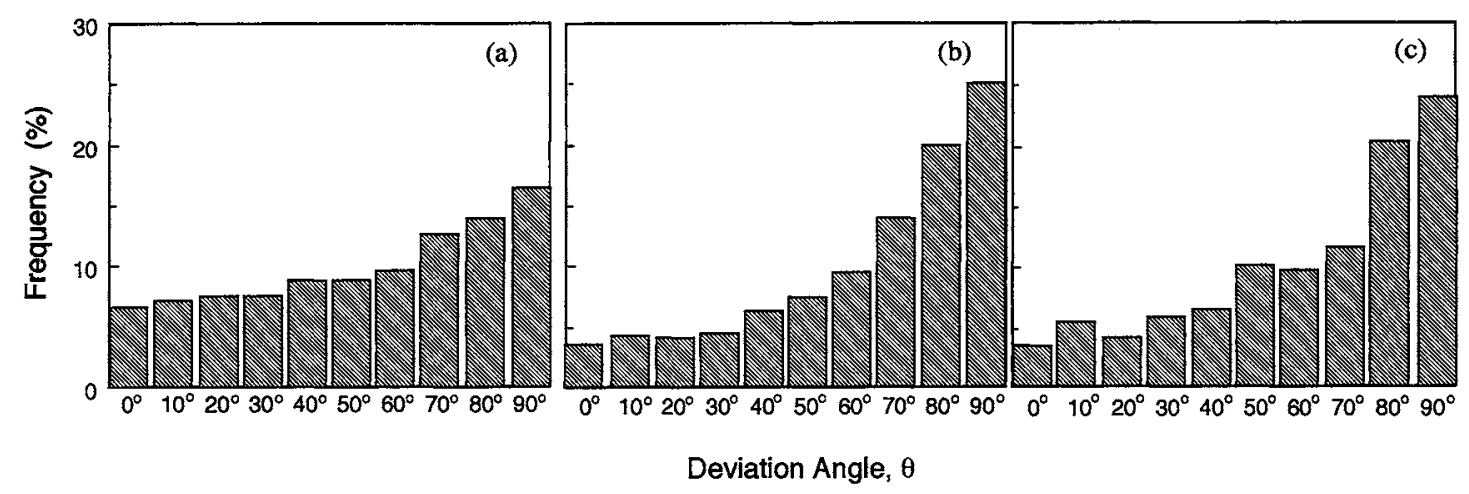

Fig. 4 Orientation distributions of dispersed particles in hot-pressed Mo/PSZ composites. ((a) 20 vol\%PSZ, (b) Mo-60 vol\%PSZ, (c) Mo-80 vol\%PSZ, Loading direction of hot-pressing: $q=0$ ).

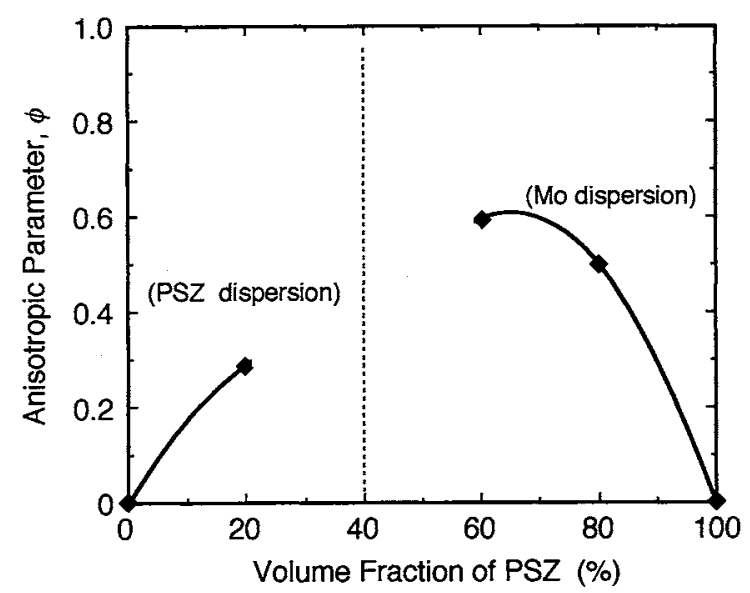

Fig. 5 Anisotropic parameter of hot-pressed Mo/PSZ composites as a function of the volume fraction of PSZ.

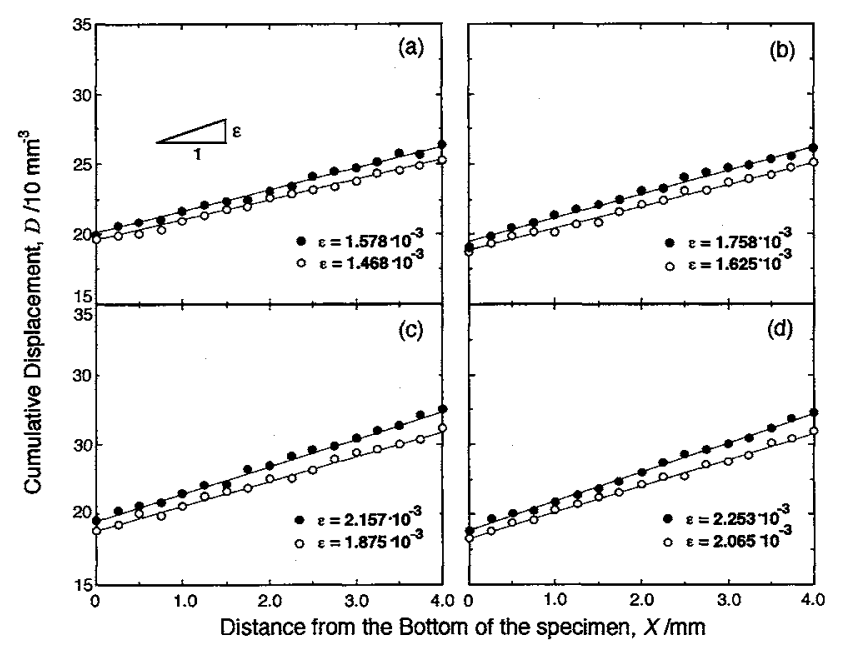

Fig. 6 Thermal displacement distributions of hot-pressed Mo/ PSZ composites. ((a) Mo-20 vol\% PSZ, (b) Mo-40 vol\%PSZ, (c) Mo-60 vol\%PSZ, (d) Mo-80 vol\%PSZ, --: parallel and -O-: normal to the direction of hot pressing, Temperature range: $573 \sim$ $773 \mathrm{~K})$.

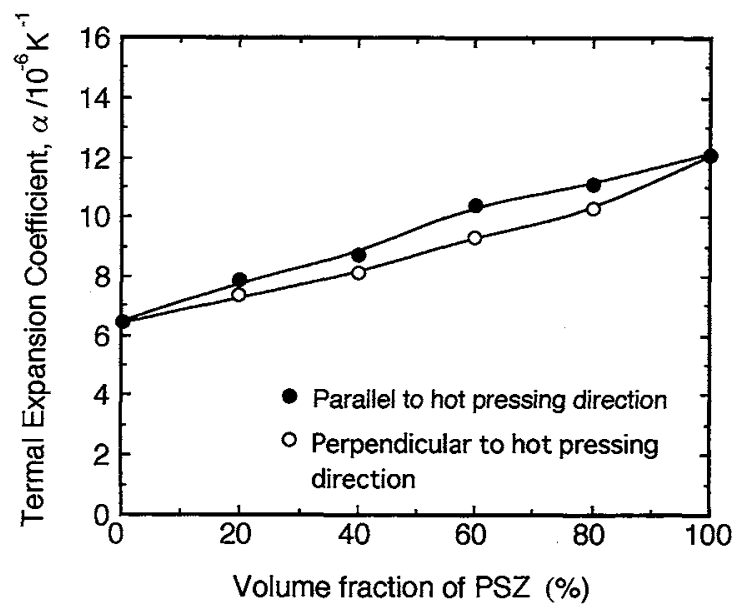

Fig. 7 Relation between thermal expansion coefficient and composition for hot-pressed Mo/PSZ composites. Temperature range: $573 \sim 773 \mathrm{~K}$.

亿熱変位は均一であることがわかる。つまり，本測定の精度内 で各焼結体の密度あるいは組織の均一性は保証されているとい 充よう.Fig. 6 のそれぞれの図中に，積算变位データの距離 X に対する变化を最小二乗法に上り直線近似し，それらの直線の 勾配から求めた熱ひずみを示した。いずれの組成においても亦 ットプレス方向の熱ひずみ梳それと垂直な方向の熱ひずみより 大きいことがわかる。

Fig. 7 亿熱ひずみを測定温度範囲， $\Delta T=200 \mathrm{~K}$ ，で除して 求めた熱膨張係数を示す. Mo と PSZ 単体の熱膨張係数はそ れぞれ $6.5 \times 10^{-6}$ と $10.9 \times 10^{-6} \mathrm{~K}^{-1}$ であり, 熱彭張の異方性 は生じていないが，混合焼結体のどの組成に和いてもホットプ レス方向の熱膨張俰数はそれと垂直な方向の熱膨張俰数より大 きい。また，組成の变化によって両方向の熱膨張係数の差，す なわち異方性の程度も異なることがわかる. Fig. 8 に，ホッ トプレス方向とそれに垂直な方向の熱膨張係数の差を組成に対 して示す。これより，熱膨張係数の異方性は明らか火組成に依 存していることがわかる.PSZマトリックスの組成側では, 


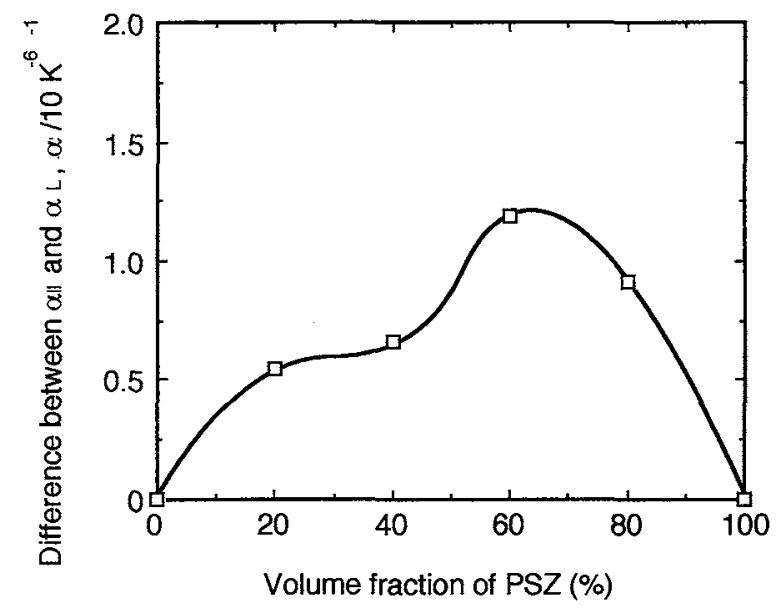

Fig. 8 Difference in thermal expansion coefficients between parallel and normal directions to hot pressing as a function of volume fraction of PSZ. $(\alpha / /$ and $\alpha 1$ are the thermal expansion coefficients parallel and normal to hot pressing directions, respectively).

Mo 分散相の体積分率の増加に伴い, 熱膨張保数の差は急に大 きくなる，Moマトリックスの組成側では，PSZ 分散相の体積 分率の増加による熱膨張係数の差の变化は PSZ マトリックス の組成側より小さい，ネットワーク組織を呈する $40 \mathrm{vol} \% \mathrm{PSZ}$ の組成では熱膨張係数差は一般的傾向よりは低く抑えられてい るように見光る。これら熱膨張係数差はすでに Fig. 5 亿示乙 た配向性パラメータの変化とよく類似している，両者の関係を 明確にするため，熱膨張係数美を配向性パラメータに対してプ ロットすると，Fig.9に示したような直線関係が得られる。 本図梳熱膨張保数の異方性が組織配向性に一義的煌存してい ることを示している.

\section{3. 異方性の微視力学的意味}

本系複合材料の熱膨張係数の異方性を，分散組織呈する組 成についてマイクロメカニックスにより理論的に考察する. 解 析は Eshelby の等価介在物法(15)(16)で行い，モデルは Fig. 10 に示すように，扁平棈円状粒子がホットプレス方向に垂直に整 列しているものを用いた．実際には正．1で述べたようと分散 粒子の配向性には分布がある. しかしここでは計算の簡略化の ために，粒子は整列配向しているものとする.

複合材料全体の熱膨張俰数 $\alpha^{\mathrm{c}}$ は微量温度变化当たりに発生 する平均ひずみであるから，温度变化 $\Delta T$ 抽よ゙ひずみの体積 平均 $\gamma^{\mathrm{D}}$ 用いて $\alpha^{\mathrm{c}}=\gamma^{\mathrm{D}} / \Delta T$ の上らに表される。ここで和 次式のようになる(17).

$$
\gamma^{\mathrm{D}}=\alpha^{m} \Delta T+\frac{1}{V_{\mathrm{D}}} \int_{\Omega} e^{*} \mathrm{~d} V
$$

ここで $\alpha^{m}$ はマトリックスの熱膨張係数， $V_{\mathrm{D}}$ は複合材料の体 積, $\Omega$ は分散相領域である。また， $e^{*}$ 恃等価介在物の eigen ひずみであり，マトリックスと分散相の熱膨張係数差により熱 応力が発生した場合には，次式に示すような Eshelby 法に上



Fig. 9 Relation between the anisotropic parameter and the difference in thermal expansion coefficient $(\alpha / /-\alpha \perp)$ for hot-pressed Mo/PSZ composites. ( $\alpha / /$ and $\alpha \perp$ are the thermal expansion coefficients parallel and normal to hot-pressing directions, respectively)

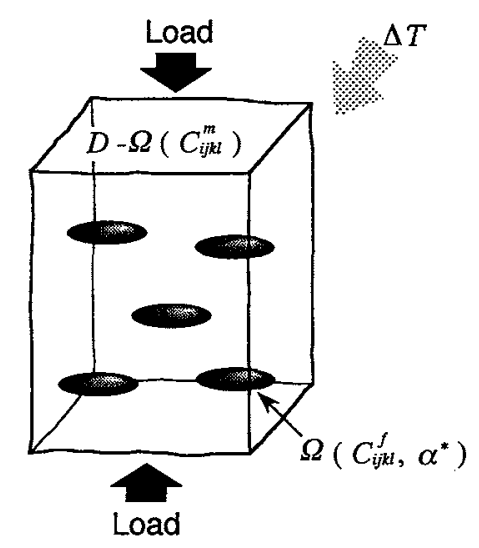

Fig. 10 Analytical model for the calculation of thermal expansion coefficient for the hot pressed Mo/PSZ composites.

り導かれる分散相内部の応力とひずみの関俰式から次式が得ら れる(18).

$$
\begin{aligned}
\sigma_{i j} & =C_{i j k l}^{f}\left(\bar{e}_{k l}+e_{k l}-e_{k l}^{T}\right) \\
& =C_{i j k l}^{m}\left(\bar{e}_{k l}+e_{k l}-e_{k l}^{*}\right)
\end{aligned}
$$

ここで $C_{i j k l}^{m}$ と $C_{i j k l}^{f}$ はそれぞれマトリックスと分散相の弾性定 数， $\sigma_{i j}$ と $e_{k l}$ はそれぞれ分散相の存在によって乱される応力と ひずみの乱れ分， $\bar{e}_{k l}$ はマトリックス中の平均弾性ひずみ， $e_{k l}^{T}$ はマトリックスと分散相の熱膨張係数差により発生する eigen ひずみである。 $e_{k l}$ と $e^{*}$ は Eshelby テンッル $S_{i j k l}$ を用いて $e_{i j}=$ $S_{i j k l} e_{k l}^{*}$ の上うな関係で結ばれており，この $S_{i j k l}$ 中以分散粒子の 形状因子であるアスペクト比が含まれている。式(3)で求め た $e^{*}$ を式 $(2)$ に代入すると複合材料全体の熱膨張係数が求を る. 単相 Mo と PSZ のヤング率はをれぞれ実測值である 317 $\mathrm{MPa}$ 扣よび $200 \mathrm{MPa}$ ，ポアソン比はそれぞれ0.35执よび0.30 を用いた(19)．分散粒子のアスペクト比は Table 2 に示した平 
Table 2 Elongation ratios of dispersed particles in hot-pressed Mo/PSZ composites.

\begin{tabular}{l|c|c|c|c}
\hline \multicolumn{1}{c|}{ Composition } & 20 vol\%PSZ & 40 vol\%PSZ & 60 vol\%PSZ & 80 vol\%PSZ \\
\hline Dispersed phase & PSZ & $\begin{array}{c}\text { Network } \\
\text { structure }\end{array}$ & Mo & Mo \\
\hline Aspect ratio & 4.22 & - & 5.04 & 4.74 \\
\hline
\end{tabular}

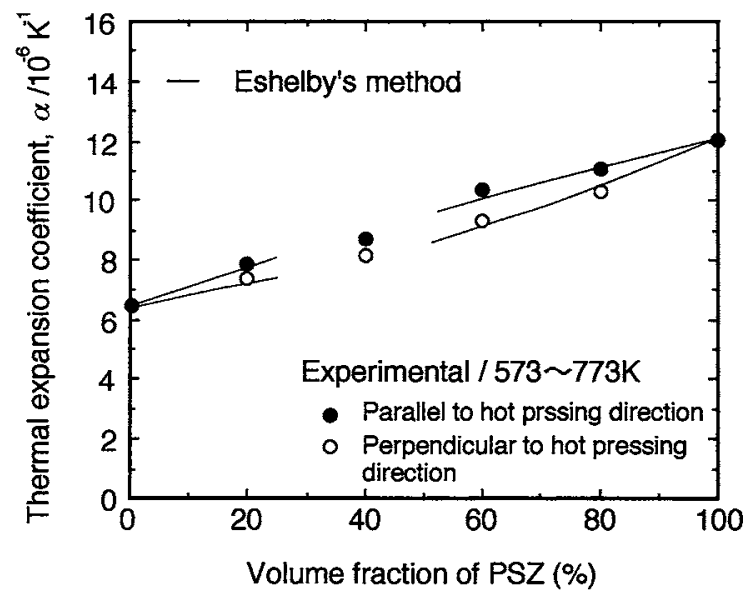

Fig. 11 Comparison of the experimental data and the prediction by Eshelby's method for the thermal expansion coefficients of the hot pressed Mo/PSZ particulate composites.

均値を用いた。な和計算の詳細は文献18を参照されたい。

Fig. 11 の曲線は，ホットプレス荷重方向に平行与よび垂直 方向の熱膨張係数の解析結果である. 分散粒子が扁平楕円体の 場合には，ホットプレスに平行方向の熱膨張係数が，垂直方向 より大きくなりこの傾向は実験值とよく一致している。すな わち分散粒子の扁平化拉よび配向が複合材料の熱膨張俰数の異 方性济影響を与兄ることが理論的にも示された。しかし， 60 vol\%PSZ 組成では，実験值は計算値より大きな值を示して いる．この原因の一つとして，本解析では一方向に整列してい る組織を仮定したが，正.1でも述べたように実際の組織は配 向分布を有しているため，その配向分布が熱膨張係数澋影を 与六たと考觉られる(20).ささらに，むら一つの原因として，熱 膨張係数がクラックやポアなどの欠宿にも敏感であることか ら, 特に, 界面剝離(4)などが生じていて熱膨張係数の異方性に 影響を与光たことも十分に考兄られる。

$$
\text { N. 総 括 }
$$

Mo/PSZ 系ホットプレス焼結複合体の熱膨張係数をレーザ
一スペックル法により測定し，その異方性を焼結組織の配向性 と関連つけて検討した結果以下のことがわかった。

（1）ホットプレスで作製したMo/PSZ 系複合体の分散相は 明瞭な配向性を有して括り，その配向の程度は組成に依存す る.PSZ相に比べMo相の配向性は上り顕著であり，60 vol\%PSZ の組成で最大の配向性を示す

（2）熱変位の測定結果からみて，ホットプレス方向和よびそ れと垂直な方向の熱ひずみ分布は均一であり，測定方向および 測定領域内に敊讨る熱膨張係数の不均一はないことが確認され た.

(3) ホットプレス方向の熱膨張係数はそれと垂直な方向より 大きい。この異方性は焼結組織に树讨る配向性に一義的に依存 し，本試料系飞おいては Mo 相分散の $60 \mathrm{vol} \% \mathrm{PSZ}$ の組成付 近で最も大きい熱膨張係数の異方性を示す.

(4) 本複合材料の熱膨張係数の異方性と組織の配向性の関係 は Eshelby モデルにより説明される。

\section{文献}

（1）川崎 亮，渡边龍三 : 日本金属学会誌，51(1987)，525,

(2) R. Watanabe: MRS Bulletin/January, 20(1995), 32.

（3）渡辺龍三, 川㥓 亮, 村橋紀昭: 素材物性学雑誌, 1(1988), 36.

（4）山田葉子，川陭 亮, 李 敬鋒, 田谷 稔, 渡辺龍三:日本金 属学会誌, 9(1992), 1078.

（5）川崎 亮, 渡辺龍三：粉体および粉末冶金, 37(1994), 253.

（6）李 敬鋒，西尾典幸，川崎 亮，渡辺龍三：粉体拈上び粉末冶 金, 41 (1994), 653 .

(7) R. Watanabe, A. Kawasaki and H. Takahashi: Proc. the Fourth In ternational MECAMAT Seminar on Mechanics and Mechanisms of Damage in Composites and Multi-Materials, held at Sant Etienne, France, Ed. by D. Babtiste, Mechanical Engineering Publication Ltd., London. (1991), 285.

（8）江莞, 川崎亮, 伊達和博, 渡辺龍三 : 日本金属学会誌, $58(1994), 835$.

(9) E. Archbold, J. M. Burch and A. E. Ennos: Opt. Acta, 17 (1970), 885

(10) E. Archbold and A. E. Ennos: ibid, 19(1972), 253.

（11）川崎 亮，渡辺龍三，島田平入，鈴木英夫：日本金属学会誌， $50(1987), 525$

（12）鈴木英夫，太田純一，島田平入，渡辺龍三：粉体拉上び粉末治 金, 33(1986), 418 .

(13) M. Taya, K. Muramatsu, D. J. Lloyd and R. Watanabe: JSME Int. J., Series I, 34(1991), 198

(14) R. Watanabe, J. Takahashi and A. Kawasaki: Proc. 3rd International Symp. Structural and Functional Gradient Materials, Lausanne, (1994), Ed. by B. Ilschner and N. Cherradi, Presses Polytechniques et Universitaires romandes, (1994), p. 3.

(15) J. D. Eshelby: Proc. Roy. Soc., London, A252 (1959), 561.

(16) J. D. Eshelby: Proc. Roy. Soc., London, A241 (1957), 376

(17) T. Mura: Micromechanics of Defects in Solids, Second, Revised Edition, Kluwer Academic Publishers, Dordrecht, (1987), 388.

(18) Y. Takao and M. Taya: Transactions of the ASME, 52(1985), 806.

（19）江 莞, 川崎 亮, 渡边龍三 : 投稿準備中.

（20）山田葉子, 渡辺龍三, 江莞：粉体怙よび粉末治金, 42(1995), 1400. 